UDC 616.126.3 - 089.843:547.962.9

Popandopulo A. G., Petrova M. V.

V. K. Husak State Institute of Urgent and Recovery Surgery of the NAMS, Donetsk, Ukraine

e-mail:pag.lctc@mail.ru

\title{
ACELLULAR MATRIX AS A SUBSTRATE FOR TISSUE-ENGINEERED GRAFT OF HEART VALVE
}

\section{ABSTRACT}

In many cases heart valve prosthetics is the only solution to save patient's life. All mechanical prosthetics currently used are not able to perform function in the body fully because non-living materials are used for their production. Tissue engineering provides the reconstruction of viable valves using stem cells. Acellularized three-dimensional tissue scaffolds as a matrix for autologous cells do improve function of heart valves and promote heart regeneration.

KEYWORDS: tissue engineering graft, extracellular matrix, autologous cells.

Terminal stage of heart valve disease is the major cause of high mortality rates. According to the World Health Organization, of the year 200817.5 million people in the world died of heart diseases that amount to $30 \%$ of all deaths [8]. Frequently, tissue or organ replacement is the sole choice. Therefore the production of long-term functioning cardiovascular implants is the common goal for researchers and clinicians in the field of cardiovascular surgery. Nevertheless, the problem of heart valve replacement by mechanical or biological prosthesis has a lot of irresolvable issues.

Currently, the mechanical prostheses are incapable to provide full adaptation to physiological environment such as pressure change and strength characteristics, since the non-living materials are used for their production [23]. For the same reason, they are not capable to grow and develop in the body, making them impossible to be used in pediatric cardiac surgery. Furthermore, the use of mechanical prostheses can cause thromboembolic disease which needs lifelong anticoagulant therapy $[17,18,23]$.

Lifetime of biological prostheses depends on the age, degeneration and calcification pronouncement leading thereby to destruction of the surrounding tissue [17]. Another important issue of biological heart valve transplantation is the lack of live cells with growth and regeneration potential.

Since the end of the last century, the scientists around the world carried out a great amount of studies aiming to determine the possibility of using the principles of tissue engineering for manufacturing valve substances with thrombo-resistant coating and viable interstitium.
These substances were meant to be able to grow and develop [10, 14, $16,25]$. A number of experiments have demonstrated the possibility of constructing viable cardiovascular structures. This has been achieved by cells application to synthetic polymers, collagen or xenogenic scaffolds [23].

At the same time, there is a hypothesis according to which tissue engineering can produce a more advanced prosthesis - alive, capable of growing, adaptable, autologous and customizable. The essence of this hypothesis is to utilize the xenogenic decellularized heart valves. To create a living autologous tissue, such valves are to possess significantly lower antigenicity and be ideal for prosthesis repopulation by recipient cells [26].

The success in creating viable autologous cardiovascular substitute depends on the three main elements: autologous cells suitable by their nature both phenotypically and functionally (1st); matrix as a temporary scaffold that provides tissue strength as long as the extracellular matrix with autologous cells has been synthesized $\left(2^{\text {nd }}\right)$; tissue formation and gaining full development in vitro conditions close to physiological ones $\left(3^{\text {rd }}\right)$ [23]. The use for this purpose of xenogenous extracellular matrix will allow receive the natural alive basis in the shortest time. Apart from already said advantages, such matrix has lower production cost making it thus more affordable for patients.

Extracellular matrix is considered in light of its role in the maintaining of the structure and three-dimensional shape of the corresponding organ. It plays the role of a dynamic connection with resident cell population. The phenotype of this population, including genetic profile, protein 
structure and functioning, depends on the micro environment (niche), namely: oxygen concentration, $p H$, mechanical strength and medium biochemistry $[5,11]$.The resident cells, in turn, secrete appropriate molecules promoting effective functioning and communication with neighboring cell populations.

Apart from the role of the matrix in the homeostasis development and maintenance, it can be used as an inductive scaffold, contributing to postsurgery remodeling response. The mechanism of this response lies in the release of latent peptides presenting mitogens and chemo attractants for the endogenous stem and progenitor cells. Also this mechanism promotes modulation of the innate immune response and provides stimulation of tissue-specific molecules for maintaining phenotype and cell functioning [11].

The matrix scaffold, made by means of decellularization, can stimulate the appropriate cell phenotype during repopulation via presentation of the ligands and biologically active molecules which are necessary for the resident and migrating cells for self-organization into functional groups created for the formation of normal structure and functioning $[11,27]$.

The extracellular matrix is composed of several major classes of protein molecules: proteoglycans, represented by the proteins coupled with polysaccharides, glycosaminoglycans; and fibrous proteins of two functional types: mainly structural (family of collagen and elastin) and adhesive (family of fibronectin or laminin) [9]. All the above mentioned proteins belong to the group of protein-carbohydrate complexes.

Collagen is the basic structural fibrillar protein of the extracellular matrix, which is found in all multicellular organisms. In the human body it makes 25 to $33 \%$ of total protein content, i.e. about $6 \%$ of body weight. Collagens are secreted by the connective tissue as well as by various other types of cells. Over 25 different collagen a-chains are known, each of which is encoded by their genes [7]. Various combinations of these genes are expressed in different tissues. Thus the predominance of a particular type of collagen is determined by the role that collagen plays in a particular organ or tissue. One of the most important properties of the collagen fibers is their mechanical strength. [29] For example, myocardial interstitium consists of a network of collagen fibers, mainly types I and II. Stiffness of heart muscle is determined by type I collagen ( $80 \%$ myocardium collagen), and elasticity by type III collagen ( $10 \%$ heart collagen), other types of collagen (II, IV$\mathrm{VI})$ are normally in small quantities [28]. Collagens are synthesized from procollagen; and this process occurs in myocardial fibroblasts [13]. Also they produce extracellular matrix proteins such as fibronectin [12].

The ability of connective tissue structures to restore shape after mechanical impact is related to a network of elastic fibers, based on the family of elastin proteins. Elastin is a hydrophilic protein which is synthesized by fibroblasts and smooth muscle cells, containing about 750 amino acids. Characteristic for elastin is the presence of two amino acid derivatives - desmosine and isodesmosine. They are involved in the stabilization of elastin molecular structure and giving it the elasticity and stretch ability [7, 27]. Like the collagen, its molecule has unusually high amount of proline and glycine. However, elastin is not glycosylated and contains little hydroxyproline and hydroxylysine.

Another group of substances is included in the structure of the matrix are glycoproteins («non-collagenous proteins»). This is a class of protein compounds with oligosaccharides (hexosamines, hexoses, fucoses and sialic acids). Glycoproteins are in the composition of both fibers and amorphous substances $[3,5,15,19]$. Fibronectin is the major fibroblast surface glycoprotein. In the extracellular space it is mainly linked with interstitial collagen. It is believed that fibronectin causes adhesion, migration, growth and differentiation of cells, providing cell-matrix interactions. Laminin is a key basement membrane component of the large adhesive glycoprotein family. It consists of three polypeptide chains linked together by disulfide compounds, as well as with type $\mathrm{V}$ collagen and cell surface receptors. Similar to the fibronectin, it is responsible for the adhesion, migration, growth and differentiation of cells $[3,7,22]$.

Fibers and connective tissue cells are enclosed in an amorphous component or a basic substance. This gel-like substance is a metabolic, integrative and multi-component buffer environment that surrounds the cell and fibrous connective tissue structures, neural and vascular elements. Among the components of the base material, there are certain organic and inorganic compounds, including soluble precursors of collagen and elastin, proteoglycans, glycoproteins, and the complexes formed by them. All of these substances are in constant motion and renewal. Glycosaminoglycans are mucopolysaccharide compounds, linear polymers, built from repeating disaccharide units. They are permeable to oxygen and $\mathrm{CO}_{2}$, but protect organs against penetration of foreign particles and proteins. Glycosaminoglycans are involved in the formation of fibrous connective tissue structures, and their mechanical properties, in the reparative connective tissue processes, in regulation of growth and differentiation of cells. Hyaluronic acid is the most common among glycosaminoglycans in the connective tissue [3, 22].

Notably that in general the structural and functional extracellular matrix molecules belong to the class of highly conservative proteins (amino acid composition of the proteins has a small variability among various kinds) that almost completely explains the absence of an immune response after xenotransplantation [11].

Thus, an important and sufficient condition of the absence of immune response to xenograft is the absence of its cellular component since the cell elements proper of the xenograft are its main inductor [24].

Of today, several methods of pre-transplant treatment of transplants have been developed. They provide a donor cell death without using crosslinking agents, and a subsequent colonization of the recipient cells prior to implantation. It is believed that this approach, in addition to reducing the immune response severity, will also reduce the interstitial calcification. [2] According to this hypothesis, recellularisation of a transplant with recipient cells may have a positive effect on the normalization of calcium and phosphorus metabolism in the tissue and its reparation. Moreover, the increase in longevity of the transplanted valve also depends on how quickly the tissue forming cells of the recipient will penetrate into the matrix of the donor valve, form a population out there, and start creating their own matrix. In this case, you can expect to self-renewal of bioprosthesis, and its further development in vivo, combined with the development and growth of the organism [5].

Of now, a variety of tissue decellularization methods has been developed in the world. All of them can be grouped into two main groups: methods, suggesting the use of substances that cause necrosis; and methods allowing decellularization by inducing apoptotic cell death. The first group fully allows achieve the desired effect within a relatively short period of time. The given methods are realized by the use of osmotic shock with distilled water; exposure in the cryoprotective mixture; processing with nucleases (DNase, RNase), proteolytic enzymes (trypsin), various surface active substances (Triton X-100, digitonin) for breaking the cell membrane $[5,15]$. Under the influence of Triton $X-100$ and trypsin a virtually complete absence of cells on the matrix is achieved. Nevertheless, both methods of treatment are destructive against elastic matrix fiber, which entails a loss of the stretchability. Lower intensity, but all the same, they have harmful effect on the collagen fibers, which are much responsible for strength of the valve matrix, especially important during diastole. Furthermore trypsin and Triton $X-100$ negatively impact on condition of glycosaminoglycans. This leads to a deformation of the valve and, as a result, to its functioning abnormality. Fibronectin, which plays a key role in the processes of cell migration and proliferation, is also amenable to the destructive effects of trypsin and Triton $X-100$. The use of chemical agents for removing of cellular elements affects the density of collagen fibers, lowering it and increasing the interfibrillar space. This process is directly related to the development of valve insufficiency after transplantation $[2,15,20]$.

The second group of techniques (apoptosis-inducing) has its obvious advantages, despite great time spending required for their fulfilment. These include, first of all, the possibility of maintaining the integrity of the extracellular matrix that is a priority requirement in the conditions of using matrix as the temporary base for the recipient cells. Such 
base gives tissues the strength to perform the given function by newly synthesized autologous matrix $[1,5]$.

Another very important task is to prevent graft calcification in postimplantation period [2]. Calcification, in this case, means the formation of calcium containing deposits on the surface or in the depth of implantable items. This process plays a positive role in reconstructive surgery of bone tissue, when implanted structures (pins, joint prostheses, etc.) are exposed to calcification. However, in case of cardiovascular grafts calcification, this leads to the loss of prosthesis functional properties and to the necessity of repeated operations. [4]

In studying the causes and course of the calcification process one should take into account the composition of calcium containing deposits and their localization, which can be internal and external [24]. In the first case the deposition is located in the depth of the material, for example, in the collagen fibers (intrafibrillary). In case of external localization, deposits are formed in the interfibrillar space or on the material's surface. Mechanical loads, to which the implant is subjected, play a significant role in the location of the deposits. Thus, calcium phosphates tend to be found in the places of intense mechanical loads, regardless of the type of prosthesis' biomaterial. Evidently, it is caused by the changes of surface energy characteristics produced by the dynamic loads and the appearance of areas with increased internal energy. Loosening of the material structure and injury of the fibers themselves is possible, using natural materials in prostheses production. This is followed by the formation of so-called «traps» for the cells or macrocomplexes, containing calcium. That further stimulates the appearance of crystallization places [6].

To understand the mechanism of biomaterials calcification it is necessary to identify the factors influencing this process. Purposedesigned experimental investigations are being carried out in vitro and in vivo. None of them have provided a complete and accurate picture. In the first case, it is not correctly to approximate data from in vitro conditions to an organism. And in the second case, a multicomponent environment of a living organism complicates assessing of one isolated factor [2]. However, the tissue with necrotic cells undergoes this process more quickly. Dead cells are essential for local change in the concentration of calcium, phosphate, proteins, lipids and enzymes. This causes deposition of soluble forms of calcium phosphates, and, under certain conditions, their transformation into insoluble ones [21].

Such widely used methods of decellularization as enzymatic treatment, hypotonic shock, treatment with sodium dodecylsulfate detergent, along with effective decellularization, do not completely suppress a calcification. Furthermore, there is a structural damage to the tissue matrix proteins after their application.

Particularly widespread is the method of decellularization with the calcium-free solution with ethylenediaminetetraacetic acid (EDTA). This avoids damages of the tissue matrix during its decellularization processing and later prevents degeneration, as a consequence of its calcification [1]. EDTA is a chelate, capable of binding calcium ions, so that the interaction between cadherins becomes broken and the physical connection of cells into a single fabric is weakened. This leads to cells dissociation.

At the same time, the higher concentration of EDTA, according to published data, is able to initiate apoptosis processes [5, 9]. Furthermore, as a chelator of calcium, magnesium and other metal ions, EDTA is used to suppress the accumulation of calcium and phosphate in mitochondria during cell death. However, it should be noted that this method of decellularization does not allow achieving a complete removal of dead cells from the depth of the matrix. Obviously, this is due to the fact that cells can migrate from the surface of the treated tissue to its depth as a result of negative chemotaxis. Nevertheless, this type of decellularization processing induces apoptotic cell death in the donor grafts. Over time, macrophages be realized it in vivo [5].

\section{CONCLUSIONS}

THREE-DIMENSIONAL EXTRACELLULAR MATRIX TISSUE SCAFFOLDS MAY SERVE AS A BASIS FOR THE AUTOLOGOUS CELLS IN PRODUCING HEART VALVE PROSTHESIS. THIS APPROACH CAN RESOLVE THE PROBLEM OF DONOR'S MATERIAL DEFICIENCY, ACCELERATE ORGAN REGENERATION AND IMPROVE LIFE QUALITY OF THE PATIENTS AFTER TRANSPLANTATION. ESSENTIAL HERE IS THE OBTAINING OF AN UNDAMAGED EXTRACELLULAR MATRIX FREE OF THE DONOR'S CELLS AND AT THE SAME TIME UNDAMAGED BY DECELLULARING AGENTS, SAVING ITS ARCHITECTURE AND POSSESSING THE COMPOSITION AND PHYSICAL PROPERTIES. IN THIS CASE, THE BIOENGINEERED HEART VALVE PROSTHESIS WILL FULLY PERFORM ALL OF ITS PHYSIOLOGICAL FUNCTIONS.

\section{REFERENCES}

1. Акатов В.С., Муратов Р.М., Фадеева И.С. и др. Изучение биосовместимости трансплантатов клапанов сердца, девитализированных антикальцинозным способом. // Клеточная трансплантология и тканевая инженерия. - 2010. - V, №2. - С. 36-41.

2. Акатов В.С., Фесенко Н.И., Соловьев В.В. и др. Подавление кальцификации трансплантатов клапанов сердца путем их девитализации. // Клеточная трансплантология и тканевая инженерия. - 2010. - V, №1. - С. 41-46.

3. Асранасьев Ю.И., Юрина Н.А., Котовский Е.Ф. Гистология, цитология и эмбриология. - М.: Медицина, 2003. - С. 315-338.

4. Барбараш Л.С., Барабаш Н. А., Журавлева И. Ю. Биопротезы клапанов сердца: проблемы и перспективы. - Кемерово: Современная отечественная книга, 1994. $-547 \mathrm{c}$

5. Бокерия Л.А., Муратов Р. М., Скопин И. И. и др. Криосохраненные аллографты в реконструктивной хирургии пороков аортального клапана. - М.: НЦССХ им. А. Н. Бакулева РАМН, 2007. - 282 с.

6. Волова Т. Г., Шишацкая Е. И., Миронов П. В. Материалы для медицины, клеточной и тканевой инженерии. - Красноярск: СФУ, 2009. - С.168-170.

7. Орловский П.И., Гриценко В.В., Юхнев А.Д. и др. Искусственные клапаны сердца / Под ред. Академика РАМН Ю.Л.Шевченко. - СПб.: ЗАО «ОЛМА Медиа Групп», 2007. - 448c

8. Всемирная организация здравоохранения. - http://www.who.int/mediacentre/factsheets/fs317/ru.

9. Таганович А. Д. и др. Биологическая химия: краткий курс лекций для иностранных учащихся стомфака. - Мн.: БГМУ, 2005. - 119 с. 
10. Bader A., Schilling T., Teebken O., Brandes G. Tissue engineering of heart valves - human endothelial cell seeding of detergent acellularized porcine valves. // Eur. J. Cardiothorac. Surg. - 1998. - 14. - P. 279-84.

11. Badylak S. F., Weiss D. J., Caplan A., Macchiarini P. Engineered whole organs and complex tissues. // The Lancet. - 2012. - 379, № 9819. - P. 943-952.

12. Czaja M.J., Weiner F.R., Eghbali M. Differential effects of gamma-interferon on collagen and fibronectin gene expression. // J. Biol. Chem. - 1987. - 262. P. 1348-1351.

13. Eghbali M. Cardiac fibroblasts: function, regulation of gene expression, and phenotypic modulation. // Basic Res. Cardiol. - 1992. - 87, № 2. - P. 183-189.

14. Elkins R., Goldstein S., Hewitt C., Walsh S. Recellularization of heart valve grafts by a process of adaptive remodeling. // Semin. Thorac. Cardiovasc. Surg. - 2001. 13. - P. 87-92.

15. Grauss R., Hazekamp M., Vliet S. et al. Decellularization of rat aortic valve allografts reduces leaflet destruction and extracellular matrix remodeling. // J. Thorac. and Cardiovasc. Surg. - 2003. - 126. - P. 63-82.

16. Hoerstrup S.P., Sodian R., Daebritz S. et al. Functional living trileaflet heart valves grown in vitro. // Circulation. - 2000. - 102, №: III. - P. 44-49.

17. Kasimir M., Rieder E., Seebacher G., Nigisch A. Decellularisation does not eliminate thrombogenicity and inflammatory stimulation in tissue-engineered porcine heart valves. // J. Heart Valve Dis. - 2006. - 15, № 2. - P. 278-286.

18. Klopsch C., Steinhoff G. Tissue-engineered devices in cardiovascular. // Eur. Surg. Res. - 2012. - № 49. - P. 44-52.

19. O'Brien M., McGiffin D., Stafford E. Allograft aortic valve implantation: techniques for all types of aortic valve and root pathology // Ann. Thorac. Surg. - 1989. 48, № 4. - P. 600-609. ,

20. Rieder E., Seebacher G., Kasimir M. Decellularized porcine and human valve scaffolds differ importantly in residual potential to attract monocytic cells. // Circulation. - 2005. - 111. - P. 2792-2797.

21. Rosanova I., Michenko B., Zaitsev V. The effect of cells on biomaterials calcification: experiments with diffusion chamber. // J. Biomed. Mater. Res. - 1991. - 25. P. 277-280.

22. Ross M., Wojciech P. Histology: A Text and Atlas. - Lippincott Williams \& Wilkins, 2010. - P. 235-241.

23. Schmidt D., Hoerstrup S. Tissue engineered heart valves based on human cells. // Swiss. Med. Wkly. - 2005. - № 135. - P. 618-623.

24. Schmidt D., Stock U. A., Hoerstrup S. Tissue engineering of heart valves using decellularized xenogeneic or polymeric starter matrices // Phil. Trans. R. Soc. B. 2007. - 362. - P. 1505-1512.

25. Shinoka T., Breuer C., Tanel R., Zund G. Tissue engineering heart valves: valve leaflet replacement study in a lamb model. // Ann. Thorac. Surg. - 1995. - 60. P. 513-516.

26. Simon P., Kasimir M., Seebacher G., Weigel G. Early failure of the tissue engineered porcine heart valve SYNERGRAFT in pediatric patients. // Eur. J. of Cardiothoracic Surg. - 2003. - 23. - P. 1002-1006.

27. Steinhoff G., Stock U., Karim N. Tissue engineering of pulmonary heart valves on allogenic acellular matrix conduits. // Circulation. - 2000. - 102, № III. P. III-50-III-55.

28. Weber K., Sun Y., Tuagi S., Cleutjens J. Collagen network of the myocardium: function, structural remodelina and regulatory mechanisms. // J. Mol. Cell. Cardiol. 1994. - 26. - P. 279-292.

29. Wilson E., Spinale F. Myocardial remodelling and matrix metalloproteinases in heart failure: turmoil within the interstitium. // Ann. Med. - 2001. - 33. - P. 623-634. 